\title{
A Rawlsian Analysis of the Plight of Bihar*
}

\author{
Paul Clements
}

\begin{abstract}
This article presents an analysis of the plight of Bihar, India's poorest state, based on Rawlsian microfoundations as contrasted with those underlying neoclassical economics and rational choice theory. While these two disciplines conceive of the individual as a rationally self-interested utility-maximizing agent, Rawls credits the individual with a reasonable as well as a rational capacity. A Rawlsian analysis, therefore, identifies and explains the principles upon which political action in Bihar has been based. Rather than focus on the failure to establish conditions for competitive markets or the maximizing strategies of political actors, this article identifies conflicts between democratic principles of equality and hierarchical principles of caste as central causes for Bihar's stark conditions.
\end{abstract}

Bihar ... has become a byword for the worst of India: of widespread and inescapable poverty; of corrupt politicians indistinguishable from the mafia dons they patronize; of a caste-ridden social order that has retained the worst feudal cruelties; of terrorist attacks by groups of "Naxalite" Maoists; of chronic misrule that has allowed infrastructure to crumble, the education and health systems to collapse, and law and order to evaporate (Long, 2004: 17-18).

\section{The Idea of the "Person" and the Role of Political Analysis}

A lthough Bihar possesses excellent agricultural lands and a large part of Alndia's mineral wealth, it is India's poorest and least-developed state. ${ }^{1}$ On the basis of India's ungenerous poverty line, ${ }^{2}$ over half Bihar's 100 million people live in poverty. In 1960 it was the fifth-poorest of India's major states, but by 1990 it had by far the highest population share below the poverty line of any state (Datt and Ravallion, 1998: 18). It was also India's only state to see per capita income decline in the 1990s (Sachs et al., 2001: 33; Thakur, 2000: 151). In 2002, 40 thousand government employees in Bihar had not been paid salaries for at least ten years (Thakur, 2002). Concomitantly, Bihar has India's

\footnotetext{
Paul Clements is associate professor of political science at Western Michigan University, and teaches primarily in the Master of Development Administration program. He received his doctorate from the Woodrow Wilson School at Princeton in 1996.
}

Studies in Comparative International Development, Winter 2005, Vol. 39, No. 4, pp. 3-29. 
lowest state literacy rate, with only 47 percent of its population able to read and write (Naik, 2001).

In this article I offer an account of Bihar's disappointing development performance, using the Rawlsian (or Kantian) idea of the "person." Two approaches in the social sciences derive their methodologies from a single, clearly articulated idea of the person: both neoclassical economics and rational choice theory assume that each individual is a rationally self-interested, utility-maximizing agent. Both approaches posit that behavior is driven by interests. Kant, however, views practical reason as consisting of two cognitive capacities, empirical and pure practical reason, associated respectively with interests and with principles (Kant, 2002 [1785]). Rawls, in adopting Kant's model, refers to these capacities as the rational and the reasonable (Rawls, 1993: 48-49; Clements and Hauptmann, 2002). I will argue that Bihar's plight is largely due to the unfolding politics of caste, at the state and village levels, in a formally democratic context. The political dynamics of caste, however, cannot be clearly understood if we think of caste as manifest only in interests. Bihar confronts us with anger, resentments, and spiraling violence that reflect an epic of competing principles. By ignoring principles or relegating them to an analytic hinterland, economic and rational choice theories obscure many of the causes for Bihar's tragic situation.

In altering the idea of the person-or, as rational choice theorists say, the microfoundations for political analysis-we not only gain analytic access to certain political dynamics: the structure and even the purpose of political analysis are also changed. The implications of the idea of the person for political thought cannot be confined to methodology.

In neoclassical economics, the idea of the utility-maximizing agent provides a basis for the theory of price formation. In a free market, price formation is driven by the choices consumers make among goods at particular prices, and these choices are assumed to maximize their utility. If we consider also the tradeoffs made by workers between income and leisure, and those made by producers among production strategies to maximize profits, we have much of the motivational force in the theory of supply and demand. This leads in turn to the ideal of the perfectly competitive market, because in such a market the interaction of supply and demand generates an efficient (Pareto optimal) allocation of society's resources. Competition drives producers to allocate resources prudently, and if markets are undistorted so that prices reflect the opportunity cost of resources, allocations that are privately profitable are also socially efficient. Consumers, workers, and producers are as well off as they can be given the distribution of assets. Given competitive markets and appropriate institutional supports, economic agents promote the social good merely by pursuing their private interests. The economic idea of the person, in this way, leads to the identification of the competitive market as a social ideal, and it is these utility-maximizing properties that make it ideal.

I should note, however, the need for appropriate institutional supports. Neoclassical economists typically adopt a functionalist approach to social institutions based on the requirements for competitive markets. Indeed, neoclassical economists in the World Bank and elsewhere have imposed an institutional 
formula on developing countries around the world. According to this formula, governments should keep their economies open to international trade and investment, maintain macroeconomic stability, minimize price distortions as they raise revenue, and provide public goods such as law and order, physical infrastructure, and education (Wade, 1990: 11; Rodrik, 1999; Kanbur, 2001). Neoclassical economic analysis of the plight of Bibar would focus on the various ways in which Bihar diverges from the competitive market ideal.

In economics, producers are thought to have interests in profits, workers in income and leisure, and consumers in the various products they purchase. "Have interest in" here serves as shorthand for "derive utility from." The central cognitive act for economic agents is the choice among a set of alternatives, and economists assume that agents assess the alternatives in terms of their probable utility to the agents. Economics has little to say about how interests come to be established. Rather, the discipline of economics assumes an interest in income on the grounds that, other things equal, agents can better pursue their interests with greater income, but generally it takes preference formation (the establishment of interests) to lie outside the model.

Rational choice theorists similarly understand choice as maximizing the satisfaction of interests, but they apply this model to a broader range of social and political situations. As income is the default interest for economists, so are wealth and power default interests for rational choice theorists. Geddes insists that rational choice theory assumes only the narrowest means-ends rationality: that people can order their goals, choose the means they consider most likely to achieve them, and have consistent preferences. The examples she gives of goals, however, such as political survival, reelection, and career survival, seem quite consistent with maximizing wealth and power (Geddes, 2003: 179-181). Bates more forthrightly refers to rational choice theory as stressing "the microeconomics of institutions" (1989: 6). Some rational choice theorists assert goals other than wealth and power and explore the constructions of interests that these goals impose on the actor's situation. Lichbach (1995), for example, analyzes the structures of interests of rebels and revolutionaries. Rational choice theory provides no basis for explaining, however, why someone might join a revolution in the early stages, when the risks and sacrifices far outweigh the likely gains.

Rational choice theory has no social ideal to parallel competitive markets for economists. Early rational choice analyses focused on how rational agents in government and in politics are unlikely to promote the social good (Olson, 1965), often exploring government failures not unlike those we find in Bihar (Bates, 1981). More recent work by rational choice theorists has considered how institutional setups can align political and economic incentives so they both support economic growth (Bates, 1989; Geddes, 1995), typically by giving political and economic actors a determinate share in the fruits of particular investments. One can imagine recommendations for Bihar along these lines. Rational choice theory tends to support a hardheaded realism and a skeptical attitude towards politicians.

The Rawlsian view of the person takes interests and principles to represent distinct, equally fundamental forms of practical reason. Conceptions of the 
good are manifest in interests, conceptions of right in principles. Rawls and Kant are primarily concerned with what Rawls calls ideal theory-that is, with how we arrive at the principles we choose to affirm. Kant's categorical imperative states (in one formulation) that you should "act only in accordance with that maxim through which you can at the same time will that it become a universal law" (2002: xviii), and Rawls argues that to assess principles of justice we should first imagine that we do not know our position in society (1999b: 16-17). The cognitive capacity that conceives moral or just principles, however, can also conceive immoral or unjust ones. Assuming that each agent's practical reason is organized in terms of principles as well as interests, Rawlsian political analysis explores the structures of principles and interests actually manifest in society.

Principles and interests are analytically distinct, but they influence one another. Kant emphasizes that as much as we may try to act morally, we cannot know with certainty how far our principles may be influenced by our interests. Turning the direction of causality around, principles have the effect of excluding some interests from consideration, and we sometimes establish interests on the basis of particular principles. Bates discusses social institutions as though they were external to (interest-grounded) agents (1989: 5, 150-154), but if institutions are external to persons one can be forgiven for wondering exactly where they are. A Rawlsian analysis views institutions as constructions of principles. While Kant identifies our freedom in our capacity to choose principles, we initially learn and adopt the principles that allow us to participate in society without necessarily articulating them. Initially they are perhaps better described as object- and context-dependent heuristics. They function cognitively as principles, but their capacity to organize cognition deepens with maturity and with explicit articulation.

Principles influence political analysis at the micro level, as we identify specific principles and explore their dynamics, and at the macro level, as analysis is framed to account for their causes, their interactions and conflicts, and their effects. Principles also influence the ideals that political analysis supports, and how we understand the functions of political analysis. I consider the macro and micro effects below, as they relate to the conditions in Bihar.

A Rawlsian or Kantian political analysis of course supports the complementary ideals of individual autonomy and social justice. As individuals we must achieve a practical mastery of some of our society's principles to secure even our basic interests. Autonomy, however, involves a secure mastery of principles of our own choosing. ${ }^{3}$ Also, as agents with principles and interests in a society of similar agents, the society's principles have a great influence on our own life prospects and on those of our families and friends, and we share responsibility for the constitution of the society's principles. As potentially autonomous agents in a society of such agents, Rawls and Kant take it that we have an imperfect obligation to support social justice both in order to realize our own autonomy and in order to support that of others. ${ }^{4}$ Both goals, autonomy and justice, are grounded in our nature as beings with the capacity to reason.

The rigorous application of rational choice microfoundations (rigorously excluding principles) leads to a view of social change as a path-dependent 
unfolding of incentive structures. Individuals are, as it were, constrained to pursue their interests, like it or not. Sometimes agents create institutions, but only to promote their interests more effectively. Thus, Bates concludes his account of Kenya's agrarian development:

When political actors intervene in the economy and seek to restructure economic relations, the policies they choose depend upon the incentives generated by the institutional context in which they are made. Economic forces generate institutions and the structure of the institutions in turn shapes the way in which governments transform their economies. Economy and policy thus interact, generating a process of change. But the process of change is path dependent; the course of the path is shaped by the initial institutional endowment. In this way, each society generates its own history (Bates, 1989: 154).

A Rawlsian analysis, by contrast, views principles as the objects by which we manifest our freedom. This is not to deny the deep roots and powerful inertia of established principles, much less the influence of interests on politics. A political analysis worthy of our dignity as free beings, however, should acknowledge our freedom.

Rawls's discussion of what he calls "burdened societies" demonstrates the pervasive significance of principles and suggests the radical freedom that results from his view of the person. Although he appreciates that some degree of economic well-being may be needed to achieve social justice, he does not define what it means to be "burdened" based on income or the satisfaction of other interests. Rather, burdened societies have historical, social, and economic circumstances that impede the establishment of a public conception of justice that supports the good of all citizens (Rawls, 1999a: 5, 90; 1999b: 4). In Rawls's view,

the causes of the wealth of a people and the forms it takes lie in their political culture and in the religious, philosophical, and moral traditions that support the basic structure of their political and social institutions, as well as in the industriousness and cooperative talents of its members, all supported by their political virtues (1999a: 108).

He further conjectures "that there is no society anywhere in the worldexcept for marginal cases-with resources so scarce that it could not, were it reasonably and rationally organized and governed, become well-ordered" (Rawls, 1999a: 108).

If we take the causes for Bihar's plight to lie largely in the principles that constitute its political and moral traditions, and ask how it could become reasonably and rationally organized and governed, we begin to see the functions that a Rawlsian political analysis must play. Conditions in Bihar indicate that something has gone terribly wrong. In order to understand its situation we must reconstruct the history that has led to the present political culture (or configuration of principles). A Rawlsian political analysis responds to the obligation to promote justice by explaining the causes of present injustices and the steps that could be taken to right them. 


\section{Rawlsian Macro-Analytics and the Politics of Caste}

The shape of a Rawlsian political analysis is influenced by the purposes it serves and by requirements arising from its subject matter. Evolution did not equip us for political economy, so if we are to respond to the obligation to promote justice we need to develop an analysis. Rawls takes the constitutionally governed nation-state to be the effective unit of social cooperation for the purpose of social justice. Since Bihar's development performance is so much worse than that of most Indian states, however, and as this should be attributed more to state-level mismanagement than to ineffective national government, we can reasonably take the state as a unit of analysis. Because vulnerable social beings with reasonable and rational capacities can organize to secure their interests and to strive for justice, a Rawlsian analysis takes it that they should. In contrast to the perfectly competitive market for neoclassical economics, the Rawlsian standard is a just society.

A Rawlsian political analysis is concerned with the satisfaction of interests, but economic growth is not its first priority. In contrast to the idea that economic growth should go on indefinitely "upwards and onwards," which Rawls describes as the idea of the business class of a capitalist society, what counts for Rawls, as for J.S. Mill, are "just basic institutions and the well-being of the laboring classes" (Rawls, 1999a: 107, n33). Extreme poverty, however, tends to preclude the development of autonomy, and a society with widespread poverty tends to be vulnerable to deep injustice. It is true that the same insight that indicates the priority that should be afforded to economic growth also suggests why this priority may be hard to establish. Nevertheless, for a place like Bihar, a Rawlsian analysis takes as its point of departure the ideal of a government that promotes growth as well as justice.

The question, then, becomes how Bihar's social institutions came to be constituted by principles so far from this ideal. This analysis begins in 1947, when India became independent, although we must look back to even earlier periods. Bihar was previously governed with reference to British objectives; from 1947 it entered upon democratic self-rule. It is no surprise that the interests of the poor were not well represented in Bihar's new government, but the concern for justice requires us to consider their perspective. We must seek to understand not only what shapes the agendas of government, but also what shapes its capacities.

We are led to a kind of historical institutionalism not only by the role of political analysis that arises from the Rawlsian view of the person, but also by the form of analysis that this view turns out to require. Because neoclassical economists often use income as a proxy for utility, and because competitive market prices convey information about consumer preferences and producer strategies, the typical form of economic analysis is quantitative. Income and prices, being numeric scalar values, lend themselves to quantitative analysis. Economic analysis employs statistical techniques to explore how rates, such as those of economic growth or poverty, are influenced by factors that economic theory recommends. Rational choice analysis is organized around the interests of its subjects, so it is formed around the configurations and dynam- 
ics of these interests. There is often a role for quantitative analysis in the rational choice approach, but the objects of many interests do not initially take numeric form. It often happens, however, that the strategic interdependency among persons resulting from their interests can be expressed in the form of a game, so game theory provides the characteristic forms for rational choice analyses. Even extended historical analyses authored by rational choice theorists tend to be organized around games and subgames (e.g., Bates et al., 1998).

Principles constitute an orientation to our interests and a framework for our relations with others. They are socially transmitted through general and context-specific formulae, and they make up a large part of our identity. Different principles may indicate mutually exclusive solutions to practical problems, so we often find them in conflict, and social conflict typically reflects competing principles as well as competing interests. Because a Rawlsian analysis seeks to present the interacting dynamics of principles as well as interests as they constitute social relations, it generally requires a longer and wider frame of reference, or a broader gauge, than rational choice theory. Rawlsian analysis seeks to explain how the system of principles that presently precludes a just arrangement came to be established.

This section introduces the conflict between the hierarchical principles of caste and egalitarian principles of democracy that commenced once India became independent, arguing that Bihar's poor economic performance from 1947 through 1990 was largely due to the organization of its politics along caste lines. I also consider how colonial rule contributed to conditions favoring caste conflict and weak democratic governance. A third section discusses the microanalytics of principles as I consider caste conflict at the village level. A fourth section employs Rawlsian analytics to explain the weak governance of Chief Minister Laloo Yadav, a talented and charismatic politician who came to power in Bihar in 1990, and whose mismanagement drove the state even deeper into poverty.

Bihar has a longstanding reputation for firmly entrenched caste restrictions, ${ }^{5}$ but it was the domination of Bihari politics from 1947 to 1967 by four upper castes that set the state's caste politics in motion. If the upper castes had been a tiny minority, as in Kerala, or if ideologically engaged political parties had already been established, as in West Bengal, caste divisions would not have become so politically salient. As it was, four castes making up 14 percent of the state population (and owning more than half the farmland) ${ }^{6}$ dominated the Congress Party in Bihar, and for the first two decades of independence the Congress Party dominated the state government.

We must inquire, therefore, into the principles that gained such significance for the state's politics. Caste is a system of ritual hierarchy maintained through restrictions on inter-marriage. Its notion of right livelihood in the fulfillment of duty is justified in terms of reincarnation and karma; high-caste individuals are thought to have earned status by dutiful action in previous lives. It divides rights and responsibilities based on notions of relative purity; thus it assigns socially necessary tasks to specific groups. Socially significant, endogamous castes (jatis) were divided from ancient times into four caste groups (varnas): brahmins, kshatriyas, vaishyas, and shudras. Brahmins were priests, kshatriyas 
warriors, vaishyas farmers or merchants, and shudras servants or commoners. Dalits (formerly called "untouchables") were a despised group below the shudras and the most impure in the ritual hierarchy (Michel, 1999: 12). ${ }^{7}$

Caste provides a basis for social cooperation by establishing principles of right relations among social groups. These principles are most clearly articulated in the religious realm of ritual; members of higher castes maintain their status through ritual performance. A sense of purity is established through various forms of abstinence; for example, as well as avoiding beef someone of a high caste may also avoid other foods like onions and garlic, and certain actions are proscribed at certain times. Of course a caste Hindu was not to touch a dalit. ${ }^{8}$ Caste is also, however, often the primary form of social organization at the village level. Where caste principles and social organization are strong, and where castes are populous enough to be politically significant, it would be surprising if caste did not become a primary basis for political mobilization.

Caste principles have several features that are politically significant. First, caste identity provides a basis for political organization that does not align neatly with divisions based on material interests. This helps the establishment of patronage networks and hinders the political aggregation of interests. Second, caste not only divides society into groups; it also identifies individuals as relatively superior or inferior. If I am of caste " $q$," according to caste principles I feel myself superior to those of caste " $p$ " (and below) and inferior to those of caste "r" (and above). Moreover, caste principles exclude lower groups from control over symbolic and material production. Consequently, caste provides a basis for higher groups to expect and demand respect and deference from lower groups.

I argued above that resentments arising from caste domination have contributed greatly to Bihar's plight, and that a Rawlsian approach is betterequipped than rational choice theory to account for resentment. This section sets the stage by explaining Bihar's political development and the influence of caste principles. The analysis is informed by the Rawlsian view of the person, with terms such as "ideology," "orientation," and "justification" reflecting the roles of principles. It would take too long, and soon become tedious, to separate out the specific roles of principles and interests in each case. Here I make the weaker argument for the general influence of caste principles within the political economy. The ongoing political salience of caste was guaranteed by the higher castes' domination of state politics for the first twenty years of independence, and by the role of political mobilization along caste lines in displacing them in 1967. Caste alignments consistently undermined the establishment of interest-based politics, caste divisions consistently increased political fragmentation, and in the context of Bihar's extreme poverty, notions of status associated with caste frequently contributed to the establishment of unproductive and counterproductive interests.

The specific brahmin and kshatriya jatis that initially dominated Bihari politics were the Brahmins, Bhumihars, Rajputs, and Kayasthas. None of these socalled forward castes was individually dominant, however, and senior positions tended to rotate among them. While they made up 14 percent of the electorate, 
the jatis from the lower or "backward" castes made up 50 percent (Mitra, 1992: 73), so if caste was to be the organizing principle of political competition, the promise of democracy was to transfer power to them. Dalits made up another 14 percent, Muslims 12 percent, and members of Bihar's tribal populations about ten percent.

The caste principles that gained political salience after 1947 were not simply those of ancient tradition. Whatever this tradition may have been in earlier centuries, it had been modified by British rule. The British had undermined some caste practices that they found particularly offensive, but by acknowledging caste in the courts and the census they strengthened the caste system, reinforcing its hierarchical features. Their establishing an all-India administration reduced the significance of local borders, and improved communication and transportation infrastructures allowed regionally based caste councils to be strengthened. By excluding native Indians from political power, they increased the residual significance of caste's minute distinctions. Bihar was particularly subject to the harsher extractive features of colonial domination. Unlike local elites in Calcutta or Bombay, those in Bihar saw little of the creative possibilities of domination. Repression and dispossession, however, such as during and after the indigo boom of the nineteenth century, were extremely harsh in Bihar. The British also intensified intra-elite conflict by sending Bengalis (mainly Kayasthas) to administer the region.

A Rawlsian analysis assumes that the character of forward-caste rule would be influenced by the particular manifestation of forward-caste principles in the earlier period. Being made to accept an inferior status and suffering the harsh restrictions and losses that the British imposed could perhaps have led to greater solidarity, but it appears that Bihar's fragmented local elites commonly sought compensation and tried to rebuild the sense of self through their own acts of domination. It is significant also that a large percentage of forward-caste landowners "do not touch the plow"; that is, they interpreted caste principles to restrict them from much of the manual labor on the farm. Some of the principles associated with land ownership may be assumed to have transferred to "ownership" of office. These factors help to explain why the Bihar state government failed to develop a corporate agenda and organization even to enhance the interests of the forward castes in the two decades following independence.

There had been no doubt that independent India would become a democracy. Sources for this commitment lay in traditions of British parliamentarianism, Enlightenment liberalism, and anti-colonial radicalism. The force of the commitment to democracy, however, was largely due to its providing an ideology for anti-colonial nationalism. This is not to impugn the democratic credentials of the members of India's independence movement but to point out that in much of India, and certainly in Bihar, the ideologically engaged leadership made up only a tiny proportion of the social elite. The establishment of institutions of democratic accountability is problematic for any ex-colony, as domestic elites take charge of a political infrastructure designed for colonial rule. In Bihar, due to the social dominance of the forward castes, demands for "home rule" effectively meant upper-caste rule. After independence, India's central 
government aimed to uplift the poor primarily through government-led industrialization. It promoted land reforms, but the constitution left policy implementation largely to the states. Since most state legislatures were, like Bihar's, dominated by high-caste landlords, it is not surprising that implementation was weak. As Kohli notes, the Indian central government "has not had the political or organizational capacity to implement [its own professed] redistributive goals" (1987: 8). Since industrialization also failed to gain the momentum expected by the planners, prospects for most Biharis would depend on developments within their own state.

Democratic governance, therefore, led to no immediate improvement in material prospects for Bihar's poor majority. The significance for them of the egalitarian principles enshrined in the nation's constitution lay largely in formal equality before the law, government policies that took equal citizenship for granted, and equal voting rights. As a poorer state Bihar has benefited from progressive allocations from some national social programs, but implementation of these programs by the state bureaucracy has often left much to be desired. Political mobilization would eventually lead to a widespread consciousness of the principle of equality; this is how democracy threatens social organization on caste principles. Democracy with universal suffrage tends to support a persistent presumption of equality, even if it may have little practical force.

To better economic conditions, the government's main task was to improve agriculture. With 92 percent of the 1960 population living in rural areas (Ravallion and Datt, 2002: 393), ${ }^{9}$ the overwhelming majority of the population depended on farming for their livelihood. The state's mining sector had something of an enclave nature; the main policy question was the formula by which the state's share of mining revenue was determined. Bihar has been home to many of India's major steel factories, with half the country's saleable steel production in 1960 (Prasad, 1997: 16). Ownership, however, has resided outside the state, and as with mining these factories have not been integrated with the local economy. ${ }^{10}$ As Prasad puts it, "Bihar was a living example of an internal colony" (1997: 16). Most Biharis' prospects for a better life, therefore, would depend on agriculture.

The government's orientation to agriculture is indicated by its approach to land reform. The Bihar Land Reforms Act of 1950 and its amendments established a contest for revenue between state government and the landlords and their middlemen. Due to the inadequacy of land records, transfer of titles from landlords to tenants was postponed. ${ }^{11}$ The immediate effect of (limited) land reform was to transfer responsibility for the collection of rents from middlemen employed by landlords to the government (Jannuzi, 1974: 20). State legislators could justify their efforts as defending themselves and their high-caste constituents against impositions from the central government. In the meantime many tenants were shifted off their traditional holdings or pushed into the ranks of landless laborers by landlords protecting against potential future land claims. ${ }^{12}$

Growth in agricultural output would depend on a mix of factors including security of land tenure, credit, agricultural extension services, irrigation (and hence, electricity), and access to fertilizer, insecticide, and improved seeds. 
The government's failure to secure these factors became particularly apparent with the advent of the Green Revolution. In 1969, Wolf Ladejinsky, a famous agricultural economist, published two articles in India's premier English-language news journal. In what has become a standard comparison, he explained that many Punjabi farmers were doubling and tripling yields with the new "miracle" seeds; and that the number of tube-wells in Punjab had increased from 7,500 in 1960 to 110,000 in 1968 (Ladejinsky, 1976: 13). Comparable statistics were not available for Bihar, but in the district used as an illustration (Purnea East), the tube-well target for 1967-1968 was 453, and even with this modest target only 92 were actually dug. Ladejinsky explained that, for agricultural regions in need of such wells, "the fundamental obstacle is lack of resources and the difficulty of securing credit of Rs. 6,000 or so to finance the construction of one" (1976: 4). Construction targets in Punjab were regularly exceeded.

Although the causes for the government's poor performance in support of agriculture should not be oversimplified, the comparison with Punjab illustrates the importance of landowners' economic strategies. While it was common for Bihari landlords to receive the greater part of their income from sharecroppers and tenants, most farms in Punjab were owner-operated. Although Bihari landlords had an objective interest in agricultural improvements, their principles, arising from economic organization and from caste, oriented them to squeezing their tenants rather than increasing their productivity. Thus, the forward castes failed to establish a political constituency for agricultural extension services.

By 1969, the forward castes had lost their opportunity. This article will not try to follow all the ins and outs of interactions between national and Bihari politics in 1967-1980. Developments in the national Congress Party, Prime Minister Indira Gandhi's suspension of many democratic rights, and the brief ouster of the Congress Party from power by the coalition Janata Party reverberated in Bihar in many ways. Congress's 1967 loss in Bihar, however, reflected in part the loss of forward-caste control over backward-caste votes. With the multiplicity of castes and of parties in Bihar, however, the result was an extended period of political confusion. Corruption was already entrenched under Congress Party rule, but the immediate result of the displacement of the Congress Party was political chaos. The opposition parties failed to form a stable coalition. There were 13 changes in government between 1967 and 1972 as Socialist, Communist, and Hindu nationalist parties, several smaller parties, and in 1972 a splinter Congress Party maneuvered for advantage (Kohli, 1990: 212-213). This frequent tumover created an extremely inhospitable environment for any incipient effort to develop a legislative agenda. Indira Gandhi's strong national victory in 1972 gave her greater influence over state governments, leading to an increase in political appointments to the civil service in Bihar, where the Congress Party had retaken the legislature. In the absence of sustained programmatic politics, legislators were perhaps well advised to promote the narrow interests of individual constituents or small groups, but as rational choice theory explains, this pattern of political exchange degenerates easily into corruption. 
Political conflict between forward and backward castes intensified after 1967, and open violence and intimidation became a major factor in the conduct of elections. This can also be seen as a continuation of the pre-independence pattern of political violence. Politicians began to commonly employ armed thugs to "capture" voting booths, frightening away opposition voters and allowing multiple votes from supporters; "Unfettered and undisciplined political competition brought criminals into the political system" (Kohli, 1990: 214).

The 1977 Janata Party victory established Karpoori Thakur, from a backward caste, as Bihar's chief minister. He attempted to build a political constituency, and to promote a pro-poor, loosely socialist agenda, by reserving seats (establishing quotas) in government jobs and in educational institutions for members of the backward castes. This action can be viewed as an alternative to (politically unattainable) land reform. Two features of Thakur's program are significant for my argument. First, his mobilization along caste lines was a tactical move informed by socialist principles. Second, he aimed to divide the benefits of government employment more fairly, not to use government programs to improve conditions for his constituency. His strategy was distributive, not productive. Perhaps the machinery of government was already too weak to sustain a programmatic agenda, or Thakur may have thought that developing such an agenda would take too long. In any case, the forward castes saw Thakur's reservations as an immediate threat to their interests as well as to the competence of government. They took to the streets, pushing political riots in Bihar to a new peak, and Thakur fell to a vote of no confidence in the state assembly (Kohli, 1990: 215, 219-220). The Janata Party failed to hold its coalition together, and in 1980 the Congress Party once more won the assembly.

That the Congress Party held the state assembly for the decade of the $1980 \mathrm{~s}$ reflected the lack of attractive alternatives and the strength of the party at the national level where it held the prime ministership. ${ }^{13}$ Political appointments to the lower ranks of government service, campaigning by caste, and the criminalization of politics continued unabated and probably increased. The backward castes, having failed to use the strength of their numbers to form a polity that could promote their interests, had neither strong political representation nor effective government. As the state remained mired in poverty, social conflicts in the villages continued to smolder and occasionally to burst into flames. The failure of interest aggregation at the state level intensified the pressures of poverty in the villages and towns.

\section{The Micro-Analytics of Principles and Social Violence in Bihar's Villages}

This analysis has attributed Bihar's increasing number of poor in the decades following independence to weak corporate coherence among the elite. The political configuration was absolutely inhospitable to social justice, but dalits and other poor Biharis might have seen their economic conditions improved if landlords and larger farmers had increased their agricultural productivity. The ways in which caste principles structured political and economic incentives undermined even this possibility. Turning now to caste-based violence in the 
villages, I first consider patterns of cognition associated with principles, then discuss the dynamics of individual principles and the effects arising from our cognition of principles, tout court.

Our cognition of principles rests on the role of intersubjective recognition in normal social relations (Honneth, 1996). In the earliest years of childhood we come to recognize the claims we make on others as those of one person on another. As our desires exceed our possibilities, we find that not all claims can be satisfied. Through instruction and autonomous insight we develop a sense of fairness, reflecting the idea that claims should be justified by reasons that are valid generally, and that what is right for one is right for another. We come to conceive of our relations with others according to principles the very grammar of which expresses our mutual dependence. Each principle rules some actions in and some out, and each principle constructs or defines a relationship, as between two persons. Although principles do not construct all relationships as ones of equality, we tend to assume a presumption of equality. Caste principles, for example, indicate that this presumption should apply among members of the same caste, and they explain why it does not apply between castes. In this way we construct a background order of principles that defines a domain of claims that we can legitimately make on others and they on us.

When someone violates our order of principles such that we cannot immediately restore it, resentment is our response. Neither economics nor rational choice theory can account for resentment, because it depends on the prior conception of an order of principles. Because caste assigns rights and duties based on criteria fixed by birth, a Rawlsian analysis takes it to be oppressive (oppression being another concept outside economic and rational choice lexicons). Dalits and persons of low caste do not experience caste principles as oppressive as long as they accept their justifications, but the establishment of democracy led inevitably, as we have noted, to an awareness of rights of citizenship. The incidence of resentment, therefore, was bound to increase.

Principles tend to reproduce themselves, in that established principles are "available" in the culture when a situation with an appropriate structural configuration arises. For example, Bihar had a long tradition of political violence prior to independence. That many had been victims and perpetrators of political violence, or had grown up with stories of it, increased the likelihood that they would find it appropriate when apparently similar conditions arose. Much of the harshest repression of dalits came from newly enriched middle-caste farmers. Finding themselves empowered by their new wealth, these farmers adopted from the caste model expectations for tenants and sharecroppers' subservience. As these agricultural workers were becoming increasingly aware of their democratic rights, the conflict of principles was potentially explosive.

In situations of asymmetrical power we should expect behavior in role context $X$, informed by principle $Y$, to have a tendency to lead to the establishment or strengthening of principle $\mathrm{Z}$. Kohli notes, for example, that from the early 1970s Bihar saw an increase in appointments to the civil service and police based on loyalty rather than merit (1990: 216). This undermines the quality of governance not only due to the appointment of less qualified personnel, but 
also by establishing obligations to benefactors rather than to professional performance on the part of appointees.

Social violence often reflects a startling disregard for interests, as it tends to impose heavy and fairly predictable costs on many if not all parties. It is intelligible, however, in the context of our overall order of principles. Our principles are interrelated, framing our conception of interests, and collectively constituting the framework for our engagement with the social world. When a central principle is violated apparently irrevocably, therefore, it is as though our cognitive world is punctured. Our conceptions of both our principles and interests may need to be reconstructed, leading not only to a temporary suspension of the calculus of interests, but also threatening our system of principles itself, our identity. Because this system constitutes the framework for our conception of interests, we cannot evaluate the threat on our interests' terms. We are therefore more susceptible to "all or nothing" logic at the same time as we may be caught up in extreme and unfamiliar emotions.

We can also see the significance of systems of principles in the effects of colonialism on caste principles. When a group is systematically excluded from political power, the normal range of its employment of principles is greatly restricted. This restriction can cause principles to be given new, narrower significations, and ironically to be affirmed with increasing rigidity. I speculate that this narrowing and entrenchment of principles, along with the weakness of competing ideologies, helps to explain the particularly strong adherence to caste principles in Bihar.

The background condition for inter-caste violence in Bihar's villages was the decline in rural incomes that began in the late 1960s: "those who own[ed] land and dominate[d] the social structure ... sought to improve their incomes primarily by squeezing those below them.... [This led to] [a]n increasing use of force to maintain subservience of labor ... [which altogether] indicates surplus-appropriating strategy that in other historical circumstances has been labeled the "second serfdom"' (Kohli, 1990: 230-231). Mitra describes prevailing conditions for predominantly dalit poor peasants and landless laborers in Bihar:

Enforcement of statutory wages has in no way benefited the labourers as the wages which are paid to them in kind is [sic] far below the statutory minimum, hardly enabling them to meet even half of their basic needs. There are no fixed working hours for labourers, as they are forced to work according to the whims of the masters. They are severely punished and humiliated even for minor errors, the modesty of their women-folk hurt time and again. There are various other ways also by which they are tortured. In a word, their misery and degradation knows no limit (Mitra, 1992: 86).

As their oppression became more forceful, groups of landless laborers and sharecroppers increasingly organized protests aiming to draw attention to the denial of these rights. They also engaged in acts of violence that shared this aim, but, by stepping further and further outside the law, also undermined it. It would be rational to anticipate that the middle and upper castes would respond to dalit violence with more terrible repression, and this is indeed what happened. Rather than considering dalit violence as simply irrational, however, or 
as "boundedly" rational but with mistaken calculations, a Rawlsian analysis takes it as a response to the puncturing of their social order and as a partially successful attempt to reclaim a dignity denied them by their oppressors. ${ }^{14}$

The impetus for protest did not come from external political forces, but external forces gave it a more highly organized expression. In the late 1960s a Maoist movement of peasant organization and violent resistance was established in several villages (including Naxalbari) in the neighboring state of West Bengal. In the early 1970s, with the support of left-wing political parties, the "Land-Grab Movement" spread to Bihar (Jannuzi, 1974: 134, 148; Singh, 2000: 104-108). Kohli shows that the "Naxalites" found their best reception in the less poor districts of central Bihar where backward castes were the up-andcoming social power. Resenting their long domination by the forward castes, backward castes, upon achieving similar economic status through increased land ownership, sought to establish a similar social status by imitating forward domination of castes inferior to their own. Absolute poverty was more severe and widespread in the northern regions of Bihar than in the central regions where the Naxalites found a welcome. However, in the northern regions it was a case of long-established forward castes intensifying their oppression. In the state's central regions, newly wealthy backward-caste landlords treated dalits particularly violently and harshly, and the dalits found this harsher oppression by upstarts to be particularly illegitimate and enraging. The highest incidence of inter-caste violence was found in Patna Division, around the state's capital city, suggesting that increased political awareness was also a contributing factor. First with the support of Naxalites, and later often without this support, many dalits of central Bihar began to organize to protest against their oppression (Kohli, 1990: 231-232).

The early 1970s was a period of increasing social unrest in Bihar's rural areas. This unrest took many forms, including the forcible mass harvesting of offending landlords' crops, illegal dalit encroachments on government lands, public rallies or demonstrations, and assassinations. The Naxalites and other left-wing parties supported and organized avenging acts of oppression and the establishment of paramilitary forces of dalits and other poor peasants, so-called red armies, that began to take control of small territories within the state. The government, however, having already demonstrated its inability or unwillingness to carry out land reform, now showed itself able neither to respond to peasant demands by addressing their grievances nor to contain the "Naxalite menace." The line between local government and police on one side, and local society of landowning families on the other, was often not a clear one. The government acquiesced in and/or supported local elite society in organizing and arming itself to put down peasant discontent. ${ }^{15}$ Since local society was typically organized on the basis of caste, this took the form of the establishment of several private caste armies. Although the hypocrisy of this selective application of the law should not escape us, the government's denial of its own principle of equality was costly. It could only be accomplished by simultaneously abdicating its monopoly on the legitimate exercise of violence.

Bihar has therefore seen a breakdown in law and order and an increase, not only in inter-caste violence, but also and inevitably in criminal violence. This 
social violence interacts with political violence, such as capturing voting booths, and with the criminalization of politics discussed above. It is inevitable in such a context that most victims would be dalits. That the landowning castes aimed to crush the violence of the serving castes and to let them know that their appeals to democratic principles were hopeless explains their adoption of terror tactics. It is commonly estimated that dalit deaths due to caste conflict outnumber forward and backward caste deaths by a factor of ten to one. Bihar became infamous, in the 1980 s and 1990s, for news reports of groups of middleand upper-caste villagers attacking nearby dalit settlements, hacking men, women, and children to pieces, burning them in their homes, and tossing them into bonfires or down wells (see Kohli, 1990: 227; Singh, 2000: 46-67).

A government paper estimated that by May 1982, 10.28 percent of Bihar's villages, 8.23 percent of the population, 9.46 percent of the net sown area, and 11.98 percent of the gross sown area had been affected by the "Communist extremist" movement (Das, 1992: 100). ${ }^{16}$ The New York Times estimated that more than 3,300 people were killed in 1986 in Bihar's caste conflicts (27 April 1987: A6; cited in Kohli, 1990: 226). Also in 1986 the newspaper India Today reported,

[Bihar] has notched up one deadly milestone after another with sickening regularity. Among the major [recent] massacres have been Parasbigha [2 February 1980; 11 killed], Pipra [25 February 1980; 14 killed], Gaini [26 June 1982; 6 killed], Kaithibigha [1 May 1985; 10 killed], Arwal [19 April 1986; 23 killed], Kansara [8 July 1986; 11 killed], and Darmia [10 October 1986; 11 killed]. Roughly one caste-cum-class carnage has been perpetrated here every four months over the last nine years (31 December 1986: 40-41; cited in Kohli, 1990: 228).

Thakur states that there were twice as many fatalities from caste conflicts in the $1990 \mathrm{~s}$ as in the $1980 \mathrm{~s},{ }^{17}$ and in 1999 Human Rights Watch made Bihar a centerpiece of its major report on India's caste violence.

In a state with a population of 100 million, only a small fraction would be directly involved in caste killings that probably number annually in the hundreds. All are affected, however, by the general sense of lawlessness and by the deep distrust that comes with it. All dalits know that local government and police have more often sided with high-caste killers than with their victims (and hundreds of dalits have been massacred by police, as well). The failure to maintain law and order is a most fundamental failure of government. It means that millions must live by their wits and strength, or live in fear. It undermines social and economic activities of many kinds. Kohli quotes the respected analyst Pradan Prasad's incredible estimate that nearly a quarter of Bihar's available land was not cultivated in 1985-1986 due to agrarian conflict (1990: 226).

\section{Laloo Yadav's Bihar}

In 1990, in the wake of the Congress Party's loss of national and state elections, Laloo Prasad Yadav became Bihar's chief minister, and over the next 
seven years he presided over a steep decline in the effectiveness of his already weak state government. Laloo (as he is commonly called) managed to mobilize broad dalit and backward-caste resentment of the upper castes, thus gaining an unprecedented personal political following. As noted earlier, analysis based on the idea of the person as a rational utility-maximizing agent cannot account for resentment, but resentment tends to displace the rational cognition of interests. Elements of the suspension of rationality are clear in the resentment Laloo mobilized, and the enthusiastic dynamic that arose between Laloo and his supporters displaced the dispassionate attention to administrative details so essential to routine governance.

In considering the conditions for the possibility of Laloo's particular form of governance, let me return to the macro-analytic themes discussed above. A polity requires some form of institutionalized programmatic accountability to support economic growth, but this was virtually absent from the political culture, or milieu of principles, that had arisen in Bihar. One set of principles displaced another, and the disorganization and petty corruption resulting from the state's fragmented politics had created conditions inimical to accountability. Democracy means "government by the people," but Bihar's history had given its people little experience with the processes this involves. The people were therefore particularly susceptible to Laloo's considerable charms.

In the 1980s, although several private armies roamed Bihar's countryside, this lawlessness affected the machinery of government only indirectly. Integrated rural development schemes, old-age pensions, school subsidies, nutrition programs, drinking-water schemes, and maternal- and child-health programs proceeded in much the same way as in other states. There was perhaps greater personalized loyalty and clientelistic service, and more caste-based clientelism in particular (see Wood, 1999), but normal activities continued. Professionalism based on specialized knowledge and training, and basic trust in the fair delivery of services, eroded gradually. The elitist government of the 1950s, the confusion of the 1960s, the national and state crises of the 1970s, and the return to familiar, if uninspired, Congress Party rule of the 1980s created a general cynicism with government and low expectations.

Laloo Yadav had won his first seat in the legislature with assistance from Karpoori Thakur, and his rise in the Janata Dal Party was largely due to assiduous political service to his superiors at the state and national levels (Thakur, 2000: 53-60). When he became chief minister, ten years had passed since his party had held that post, so he had little experience legislating from the ruling party. More importantly, the state assembly that he entered had little tradition of programmatically effective governance. His legislative experience was mainly one of opposition to a Congress Party which was continuing to degenerate into clientelism and corruption. Laloo had no administrative experience to speak of, and he cannot entirely have escaped the casual cynicism that pervaded state government.

Laloo initially appropriated Gandhian symbols of leadership: living in his brother's two-room apartment at the Patna Veterinary College, holding Cabinet meetings out of doors under a tree, standing in a public queue to have his 
son's fever treated at the Patna Medical College. The distinguishing feature of his reformist efforts, however, was their personal nature. He himself took a megaphone to clear traffic at a busy intersection. He himself would show up at government offices and police stations to punish corrupt officials (Thakur, 2000: 72-76).

A member of the backward Yadav caste, Laloo was familiar with caste discrimination from his own childhood. When the Prime Minister decided to implement the Mandal Commission's recommendation to reserve 27 percent of central government jobs for members of the backward castes, Laloo vocally supported the policy. This gave him the opportunity to develop his rhetoric of caste liberation. While Karpoori Thakur had appealed to backward-caste interests, Laloo presented himself as a man of the people who would right the historic injustices perpetrated by the upper castes. Hence, his slogan was to "wipe out the upper castes." The irony of the enthusiastic and widespread support that he received from the backward castes and from dalits was that many of the very actions he took to promote their interests had the effect of undermining the competence of government on which strategies to improve their interests would depend.

Laloo soon became a master of the politics of symbolism, but sometimes this political approach was practically effective. In 1991, Lal Krishna Advani, president of the Hindu nationalist Bharatiya Janta Party, led a procession through Bihar on the way to Ayodhya, in the neighboring state of Uttar Pradesh, where there is a mosque built over a Hindu temple. ${ }^{18}$ Members of the Bharatiya Janta Party were calling for the destruction of the mosque to rebuild the temple, and Laloo took the procession to be an incitement to violence between Hindus and Muslims and had Advani arrested and his procession turned back. This action, and his vocal guarantee to protect Muslims from Hindu violence, won Laloo enthusiastic support among the Muslims who made up 12 percent of Bihar's electorate, and indeed Muslims were safe under Laloo's rule (Thakur, 2000: 78-82).

In 1991, Laloo's party won the Lok Sabha (national parliament) elections in Bihar, demonstrating the effectiveness of his approach, and Laloo became accustomed to entertaining enthusiastic crowds. It is easy to imagine that he conceived of himself in something of the manner of a benevolent fairy-tale king (Das, 1998: 2959). When he saw a problem he would rush to set it right. He would command his ministers, and they would obey. Laloo's very popularity, however, gave him license to ignore the general implementation of government programs. As a senior official recounted,

Laloo Yadav was a headache for officers, a nuisance and a nightmare. He would stop at the roadside and order a set of dwellings for the poor to be built without caring whether the land was the government's or where the money would come from. He would dismiss officials and not wonder about replacements. He would make announcements and expect the administration to implement them without providing the means. Laloo Yadav had no idea how the administration ran, and he did not care to learn either.... He just gave orders and expected them to be implemented, anyhow (Quoted in Thakur, 2000: 87). ${ }^{19}$ 
The first years of Laloo's rule saw flurries of government activity around the state: rural vocational schools established for shepherd boys, housing blocks established in slums, roads built to villages. At the same time he increased political appointments to the civil service and other clientelistic practices.

The administration of government deteriorated. From 1992 to 1996 the state spent only 20 percent of Bihar's allocation from the central government's eighth five-year plan, while hundreds of government employees were left unpaid and the public debt mounted (Chaitanya, 1996: 993). State-run services in education, health, electricity, and housing collapsed (Sinha, 1996: 3287). Audits of the 50-some state treasuries declined from more than 20 in 1989-1990 to none at all in 1994-1995, while indications of corruption and fraud increased. In the irrigation department, expenditures on works declined by 58 percent from 1991 to 1994 while expenditures on salaries increased by 42 percent. According to K.P. Joseph, "the system of financial control through legislative scrutiny of budgets and accounts no longer exists in Bihar" (Joseph, 1997: 1687).

In 1995, Laloo stunned the nation when his Janata Dal party won an absolute majority in Bihar's legislative assembly. Janata Dal won only 28 percent of the vote, but with six other national parties and many local parties dividing the remaining votes, this percentage was enough to win 52 percent of the seats (Press Information Bureau, 2000). Two backward castes defected from Janata Dal to form their own party, but Laloo received strong support from Muslims and even stronger support from dalits and from other low castes. Rational choice theory can account for Laloo's political strategies as serving his interests, but it can hardly account for the enthusiasm of the backward caste and particularly of the dalit response. It might offer the notion of bounded rationality to account for dalit support for a program that in fact undermined their material well-being. A Rawlsian viewpoint gives credence to resentment arising from centuries of oppression. Laloo Yadav spoke to the backwards and even to dalits as one of their own. He was with them against the forward-caste authorities, and they identified with him (Gupta, 1995: 790). The crowds that gave him their adulation saw him as moving to set old scores right, a view for which the categories of rationality and irrationality are simply inadequate.

While Laloo's sustained popularity is intelligible in the context of the history of caste oppression, its intelligibility is contingent on his supporters not understanding the consequences of his governance for their objective interests. We need to be cautious here, because Laloo's government did deliver additional services to some dalits and members of backward castes. The quality of government services overall continued to decline, but the support of low caste citizens was certainly not entirely irrational. The political dynamic that their support set in motion, however, was a perversion of the notion of democratic accountability. Because caste politics had displaced programmatic politics, and because a cynical accommodation of personal deals had become so routine as to be part of the fabric of political life, people were vulnerable to Laloo's appeal. His appeal took the form of a logic of resentment, and this logic resonated with many listeners. Yet his regal manner of conducting the 
affairs of government, while simultaneously plundering it for patronage, inevitably corroded the bureaucratic arms of the state.

After his victory in the 1995 elections, Laloo made tentative moves to encourage foreign investment in Bihar. These moves were showing little sign of success, however, when he became embroiled in the corruption scandal that drove him from office in 1997. A racket based on fraudulent invoicing had been established in the Animal Husbandry Department in the 1980s, and its scale of operations increased dramatically under Laloo Yadav. Withdrawals from the state treasury in excess of the department's total budget increased from 17 percent in 1988-1989 to 53 percent in 1990-1991, 169 percent in 1993-1994, and 229 percent in 1994-1995 (Thakur, 2000: 123). Press reports suggested that as much as Rs. 950 crore (about US $\$ 200$ million) was stolen (Joseph, 1997: 1686). After the central government's investigative bureau charged him with several offenses and was preparing to have him arrested, Laloo Yadav resigned (leaving his wife, however, as chief minister).

\section{Elements of a Reform Agenda}

There are two branches to the reform agenda this article promotes-one analytic, the other political. I suggest that an analysis on Rawlsian microfoundations provides a better explanation for Bihar's plight than would an analysis based on the idea of the person as a rationally self-interested, utility-maximizing agent, whether of the neoclassical economic or rational choice variety. Neoclassical economists would focus on Bihar's distance from the conditions for competitive markets, due perhaps to the lack of infrastructure and public goods, or perhaps to the lack of free-market government policies. Rational choice theorists would focus on the configurations of interests in key institutions, possibly the same institutions I have emphasized: the state legislature, the economic bureaucracies, and the institutions governing control of land and labor in the countryside. They would analyze these institutions in terms of a game theoretic logic in which the desire for wealth and power are the main motive forces, explaining Bihar's sub-optimal outcomes as the result of the players' maximizing strategies.

While both of these analyses capture significant features of Bihar's experience, the focus on interests leads to a perspective that is narrow and reductionistic. My Rawlsian analysis is broader in both ambition and methodology. Game theoretic analysis of particular institutions is not enough for agents with principles as well as interests. In order to realize their freedom, they need an analysis that can orient them both to society's productive features and to its (in)justice. In order to understand Bihar's declining productivity in the 1990s, the Rawlsian analyst needs to explain the principles of Laloo Yadav's political project. This takes us in several directions: to the way caste politics had undermined the programmatic competence of the legislatures in which he received his political education; to Bihar's history of oppression and consequent pools of resentment, resentment heightened by democratic politics and governance based nominally on citizens' equality; to Laloo Yadav's personal experience of oppression that gave him the resources to channel popular resentment and make 
it a political force; and to the history by which the people were unable to see the consequences of Laloo's politics for government competence.

To understand Bihar's earlier economic failures from the 1960s through the 1980s, we are confronted with that most difficult question: why certain things did not happen. The license to ask this question derives precisely from Bihar's exceptionalism: poverty increased in Bihar while it declined in other states. I have argued that the answer to this question is bound up in the principles of caste politics and in the particularly severe oppression that Bihar experienced under colonial rule, as well as in interactions with national politics and a variety of factors that contributed to Bihar's political confusion. Due partly to its colonial experience, Bihar had a stronger and more ossified caste system than other states, and a governing class more oriented to extractive than to productive economic strategies. While dominating government from 1947 to 1967 , the forward castes "missed the boat" to the Green Revolution, and in establishing patterns of political mobilization based on caste they created conditions for the political confusion that followed the inevitable end of their hegemony.

Economic failure, caste principles, and injustice are even more tightly bound together in the rural violence that took so much land out of production in the 1980s (and presumably thereafter). I have argued that the particularly extreme violence in Bihar's central regions, which are not the site of the state's most severe poverty, is due largely to the particularly harsh repression imposed by middle-caste farmers trying to climb the caste ladder. The violence of the $1980 \mathrm{~s}$ and 1990 s has roots as far back as the nineteenth-century dispossessions associated with the rise and fall of indigo markets. Principles of domination, subjugation, and violent resistance have cycled through Bihar's history, so when local elites are enraged by dalit demands for equal implementation of the law, they are more prone to resort to violence. But the frequent massacres of dalits are attributable as much to the government's failure to contain them as to the passions that incite them.

Recall that a Rawlsian analysis should explain the elements of Bihar's political culture and moral traditions as they contribute to the basic structure of the state's political and social institutions. My summary account, therefore, proceeds as follows: (1) A poor agricultural society like Bihar's needs a government that can carry out certain kinds of investments, and (2) the ways in which Bihar's upper castes have been accustomed to treating dalits, particularly the manner of their incorporation in the agricultural workforce, are inconsistent with dalits' rights as citizens of a democracy. Since India won its independence, if Bihar was to establish a public conception of justice that would support the good of all its citizens, such a conception would have to address these two problems. The landed elites who initially governed Bihar, however, did not appreciate the need for government to promote a productive agenda, nor were they prepared to undermine their own caste status. The agendas of incumbents in subsequent governments tended to focus on their own narrow and short-term advantage, rather than encompassing, productive projects. Lacking statesmen promoting a unifying framework, politicians mined the civil service. As government failed to support agricultural improvements and rural poverty increased, oppression rooted in the caste system increased 
as well. Dalits and other laborers, recognizing the oppression as a violation of their rights but getting little support from government, sometimes struck out in violence, and the upper castes responded with even more violent repression. At the state level the debased political culture established the opportunity for Laloo Yadav's politics of resentment, which in turn engendered further declines in government competence. Thus Bihar lacks the reasonable and rational organization and governance that it would need to become, as Rawls says, well ordered. The two problems it has faced since independence still remain to be overcome.

On a more speculative note, I would like to suggest that Rawlsian microfoundations provide the implicit but as yet unarticulated grounds for the structuralism that scholars of comparative politics (largely) take for granted. To see the structuralist features of the proposed methodology, it is useful to compare it with the interpretivist perspective recently adopted by Susanne Hoeber Rudolph and Lloyd Rudolph, two of the West's foremost scholars of modern and contemporary India. Through much of their careers, Rudolph and Rudolph have sought to advance the same political economy tradition claimed by a Rawlsian approach. Over the last two decades, influenced by postmodern trends in the social sciences and humanities, they have sought to make their analyses more sensitive to, and even congruent with, the conceptual fields of the subjects of their analyses. Movement in this direction can be seen in their In Pursuit of Lakshmi: The Political Economy of the Indian State (1987). Although a classic of political economy, as the term Lakshmi-the Hindu goddess of wealth-in the title suggests, this work also seeks to bridge the conceptual divide between India and the West by employing a language that draws concepts from both (393-394). The effort to represent and to probe the subject's conceptual field is in full flower in Reversing the Gaze: Amar Singh's Diary, A Colonial Subject's Narrative of Imperial India (2002), edited by Rudolph, Rudolph, and Mohan Singh Kanota. The technique of representing the conceptual fields of diverse subjects is demonstrated in Rudolph and Rudolph's article, "Living with Difference in India" (2000), on the contest between legal pluralism and legal universalism.

At this point we need to distinguish between two kinds of interpretivism. Rudolph and Rudolph are certainly right to criticize Western scholarship for blindness and insensitivity in blithely applying concepts and categories from other contexts without modifying and fine-tuning them to fit Indian social realities, and also for using India (as, say, "the other") to promote Western academic pretensions and ambitions without respecting Indian claims to autonomy. One can imagine an interpretivism that seeks, self-effacingly, to organize itself so fully within the subject's frame of values and references that the scholar's interpretive framework almost recedes from view. This could produce interesting work, but it is not what Rudolph and Rudolph attempt. Their interpretivism is driven by the range of humanistic values-such as equity, efficiency, integrity, mutual respect, and the realization of potential--that political economy scholarship takes for granted. One might say that their interpretivism rests on, modifies, and serves political economy. What their interpretivism makes implicit, and what the self-effacing interpretivism gives up, is the concerns and the analytic technique arising from the experienced 
political economist's familiarity with a range of practical problems that are in fact universal among human societies.

Compared to Rudolph and Rudolph's interpretivism, a Rawlsian analysis is explicitly structuralist and normative. It is structuralist in perceiving that one task of analysis is to articulate the structures of principles and interests that constitute political life. It holds that each society presents an answer to problems of production, distribution, social order, defense, and reproduction, and that the potential scope and form of these "answers" is conditioned or compelled to regularity both by the cognitive capacities we bring to them and by their material features as practical problems. It is normative in generating not only a methodology but also an orientation, which we have expressed in the concern for justice and for capital accumulation.

This brings us to the political branch of this article's reform agenda. The poverty-reduction literature on Bihar tends to focus on programs that could be carried out for this purpose. Sachs, Bajpai, and Ramiah, for example, argue that Bihar needs investments in physical infrastructure such as roads, railways, airports, and telecommunications, and in human capital, mainly education and health (2001: 24). Sharma argues for public investment in irrigation, flood control, drainage, rural electrification and generation of rural power supply, and for poverty-alleviation programs that improve the productivity of the poor, such as credit, wage-employment, and literacy programs (1995: 2601). In their review of the causes of chronic poverty in India, Mehta and Shah (2003) state that the vast literature on reducing India's poverty falls into three main categories. A structuralist view (similar to my own) argues for reducing inequality in land and capital and for breaking barriers of social stratification (e.g., caste restrictions). An "efficiency of growth" view argues that since major redistribution is politically impossible, strategies should focus on developing input and credit markets in poor regions to support agriculture-led economic growth. Such growth would in time absorb labor and thereby reduce poverty. A "residual" view argues for providing safety nets and targeting social security to the poor (2003: 505-506).

A Rawlsian view sees the causes for Bihar's poverty in the configurations of principles and interests that have come to constitute political life at the village and state levels, and its reform agenda is unashamedly voluntaristic. It seeks a change in principles. The legacy of oppression must be halted. In order to establish a politics based on notions of common interest, backward- and forward-caste landowners must accept the equal humanity of their laborers. This is a long-term project; initially, in order to establish peace in the countryside, the democratic rights of dalits and of other laborers and sharecroppers must be protected-a goal that involves enforcing laws on workers' rights and probably some land tenure reform. Proponents of the rights of the poor should recognize that violent resistance leads to violent repression. It is the duty of government to protect citizens' rights; the reformer's task is to help the government to acknowledge this duty and to carry through its obligations. In defending the rights of workers, there are roles for central and state government, for social reformers, for enlightened landlords, and for the lower castes themselves. 
The second item on a Rawlsian reform agenda for Bihar is to increase agricultural productivity. Given the state's extreme poverty, sustained improvements in economic and social conditions require improvements in agriculture. This requires more effective management of agricultural extension and credit services, electricity generation and distribution, flood control, and other government activities in support of agriculture. It is clear, however, that development specialists have known for decades that Bihar needs these improvements. Reforming government so it can provide them is a political problem. What stands out throughout Bihar's post-independence history is the failure to build an administration that is competent to carry out development investments. We can imagine that strengthening government's administrative machinery, and particularly government management of support for agriculture, could be the task of a Rawlsian political party. If it is the declining quality of Bihar's political discourse that has led to the recent economic stagnation, it is reasonable that a discourse better grounded in actual interests and in just principles should be part of the solution. A Rawlsian party would seek votes by defending peasants' rights and by promoting a programmatic agenda that could improve voters' economic and social conditions.

\section{Notes}

* I am grateful for comments and suggestions from Emily Hauptmann, Jacinda Swanson, Atul Kohli, Peter Stone, Stephen Jackson, Lucinda Dhavan, from the editors at Studies in Comparative International Development, and from two anonymous reviewers. Suggestions from one reviewer were particularly helpful for the article's articulation of the Rawlsian roots of the proposed analytic approach, and the integration of the theoretical and empirical arguments owes much to the editors.

1. In 2001, Bihar was split into two states, with the mineral-rich southern portion named Jharkhand. All references in this article refer to pre-2001 Bihar.

2. The poverty line of the Planning Commission of the Government of India is Rs. 49 per capita monthly expenditure for rural areas and Rs. 57 for urban areas in 1973-1974 prices, enough to sustain a diet of 2400 calories per day in rural areas and 2100 calories per day in urban areas (Ravallion and Datt, 2002: 397). This corresponds to an annual income of $\$ 73$ for rural areas and $\$ 84$ for urban areas at the 1974 Indian rupee:U.S. dollar exchange rate.

3. Kant takes it that we find our autonomy in choosing principles consistent with the categorical imperative.

4. An imperfect obligation is one we should pursue when and how we choose; it does not require a particular action at a specific time.

5. Gandhi writes on his first visit to Patna, the state capital, "There was strict untouchability in Bihar. I might not draw water at the well whilst the servants were using it, lest drops of water from my bucket might pollute them, the servants not knowing to what caste I belonged" (1927: 306).

6. Based on an early 1980 s survey of 2,531 households, Kohli lists upper ("twice-born") castes as comprising 82-percent of Bihar's farmers with over 10 acres of land and 71 percent of farmers with 2.5 to 10 acres. However, upper-caste households made up 25 percent of the farming households surveyed (1990: 210). The survey results come from an unpublished report: P. H. Prasad and G. B. Rodgers, "Class, Caste and Landholding in the Analysis of the Rural Economy," Population and Labour Policies Programme, Working Paper No. 140, World Employment Programme Research (Working Papers), International Labor Office, Geneva, 1983, table 1, p. 12.

7. Because the status of a particular caste is sometimes contested, it is not always clear to which varna a particular jati belongs.

8. Nussbaum writes that, "throughout history, certain disgust properties-sliminess, bad smell, stickiness, decay, foulness-have repeatedly and monotonously been associated with, indeed projected onto, groups by reference to whom privileged groups seek to define their superior human status. 
Jews, women, homosexuals, untouchables, lower-class people-all of these are imagined as tainted by the dirt of the body" (2001: 347).

9. Falling only to 87\% percent by 1991 (Sachs, Bajpai, and Ramiah, 2001: 39).

10. While Bihar has had small-scale artisanal production of iron for centuries, the state's steel manufacturing was initiated in 1913 by the Tata Iron and Steel Company (Sinha, 1988: 23).

11. Bihar's Survey and Settlement operations to establish official land records were still not completed as of 1970 (Jannuzi 1974: 21n).

12. According to Jannuzi, "the amendment act of 1959 continued to focus on the primary interests (land revenue and compensation) of the principal antagonists, rather than on the interests of the peasantry having a direct cultivating interest in the land. Nowhere in any of this 'land reform' legislation were the interests of the landless laborers or 'bataidars' (sharecroppers) considered" (1974: 28). The majority of tenants find their plots changed every year or two so they cannot claim occupancy rights. A 1980-1981 study found 28 percent of Bihar's cultivated land under tenancy, mostly in sharecropping arrangements. Although the law sets a maximum of 25 percent of the gross produce for rent, most tenants pay half their crop to the landlord, and up to 75 percent when the landlord shares the cost of inputs (Sharma, 1995: 2594).

13. "Throughout the 1980s, the Congress government was unable to act with even a modest degree of cohesiveness. Much of the leadership's attention was focused on political intrigue. Solving the state's pressing economic and political problems was far from anyone's mind" (Kohli, 1990: 224).

14. Rational choice theory can explain any choice as the reflection of the agent's (however oddly shaped) utility function, but when the suggested utility function is not related to the agent's interests as rational choice theorists generally understand them, the connection with rational choice analysis is severed.

15. The Indian Nation reported on 28 May 1975 , "The Bihar government has decided to arm all ablebodied persons in Bhojpur and Patna districts for self-defense to face the extreme menace, who have recently launched an armed struggle. ... District magistrates of both the districts have been asked to visit the affected villages and issue licences [sic] for firearms on the spot to those who were able to possess them.... The decision was taken following a spurt in the armed attacks on landowners by the extremists in these villages" (quoted in Kohli, 1990: 218-219).

16. Similar statistics are cited in Kohli, 1990: 224 from Government of Bihar, "Notes on Extremist Activities-Affected Areas," mimeograph, 1982.

17. Thakur writes that there were 481 caste-related killings in the 1980 s and close to a thousand in the 1990s.

18. The site is believed to mark the birthplace of Rama, a revered Hindu deity.

19. See also Das, 1998: 2959.

\section{References}

Bates, Robert H. 1981. Markets and States in Tropical Africa: The Political Basis of Agricultural Policies. Berkeley: University of California Press.

. 1989. Beyond the Miracle of the Market: The Political Economy of Agrarian Development in Kenya. Cambridge: Cambridge University Press.

Bates, Robert H., Avner Grief, Margaret Levi, Jean-Laurent Rosenthal, and Barry R. Weingast. 1998. Analytic Narratives. Princeton: Princeton University Press.

Chaitanya, Krishna. 1996. "Bihar: Opportunistic Alliances and Shifting Party Loyalties." Economic and Political Weekly 31, 16-17: 993-994.

Clements, Paul and Emily Hauptmann. 2002. "The Reasonable and the Rational Capacities in Political Analysis." Politics \& Society 30, 1: 85-111.

Das, Arvind N. 1992. The State of Bihar: An Economic History without Footnotes. Amsterdam: VU University Press.

. 1998. "Para-Democracy in Bihar." Economic and Political Weekly 30, 15: 2959-2960.

Datt, Gaurav and Martin Ravallion. 1998. "Why Have Some Indian States Done Better than Others at Reducing Rural Poverty?" Economica 65, 1: 17-38.

Gandhi, Mohandas K. 1927. An Autobiography or The Story of My Experiments with Truth. Translated from Gujariti by M. Desai. Ahmedabad, India: Navajivan Publishing House. 
Geddes, Barbara. 1995. "Challenging the Conventional Wisdom." Diamond, Larry, and Marc F. Plattner, ed., Economic Reform and Democracy. Baltimore: Johns Hopkins University Press.

- 2003. Paradigms and Sand Castles: Theory Building and Research Design in Comparative Politics. Ann Arbor: University of Michigan Press.

Gupta, Tilak D. 1995. "Bihar: Elections with a Difference," Economic and Political Weekly 30, 15: 789-792.

Honneth, Axel. 1995. The Struggle for Recognition: The Moral Grammar of Social Conflicts. Cambridge, UK: Oxford University Press.

Jannuzi, F. Tomasson. 1974. Agrarian Crisis in India: The Case of Bihar. Austin: University of Texas Press.

Joseph, K.P. 1997. "Lessons from Bihar Fodder Scam." Economic and Political Weekly 32, 28: 16861687.

Kanbur, Ravi. 2001. "Economic Policy, Distribution and Poverty: The Nature of Disagreements." World Development 29, 6: 1083-1094.

Kant, Immanuel. 2002 [1785]. Groundwork for the Metaphysics of Morals. Edited and translated by Allen W. Wood. New Haven: Yale University Press.

Kohli, Atul. 1987. The State and Poverty in India: The Politics of Reform. Cambridge: Cambridge University Press.

- 1990. Democracy and Discontent: India's Growing Crisis of Governability. Cambridge: Cambridge University Press.

Ladejinsky, Wolf. 1976. "The Green Revolution in Bihar-The Kosi Area: A Field Trip; The Green Revolution in Punjab: A Field Trip," Agricultural Development Council Reprint No. 28, New York. Reprinted from Economic and Political Weekly 4, 39 (27 September 1969), and 4, 26 (28 June 1969).

Lichbach, Mark Irving. 1995. The Rebel's Dilemma. Ann Arbor: University of Michigan Press.

Long, Simon. 2004. "India's Shining Hopes: A Survey of India" Country Survey Insert, The Economist, 370, 8363, 21 February.

Mehta, Aasha Kapur and Amita Shah. 2003. "Chronic Poverty in India: Incidence, Causes and Policies." World Development. 31, 3: 491-511.

Michel, S. M., ed. 1999. Dalits in Modern India: Vision and Values. New Delhi: Vistaar Publications.

Mitra, Roma. 1992. Caste Polarization and Politics. Patna, Bihar: Syndicate Publication.

Naik, S. D. 2001. "Census 2001: Disturbing Inter-State Disparities," Business Line Internet Edition, 3 April 2001, at www.blonnet.com/businessline/2001/04/03/stories/01032001.htm.

Nussbaum, Martha C. 2001. Upheavals of Thought: The Intelligence of the Emotions. Cambridge: Cambridge University Press.

Olson, Mancur. 1965. The Logic of Collective Action; Public Goods and the Theory of Groups. Cambridge: Harvard University Press.

Prasad, Kedar Nath. 1997. Bihar Economy Through the Plans (In comparison with All-India and other States). New Delhi: Northern Book Centre.

Press Information Bureau, Government of India. 2000. "Bihar Legislative Election-1995" Latest PIB Releases, '13,' accesed May 2003, http://pib.nic.in/archieve//releng/lyr2000/rjan/2000/ r31012000.html.

Ravallion, Martin and Gaurev Datt. 2002. "Why Has Economic Growth Been More Pro-Poor in Some States of India Than Others?" Journal of Development Economics 68: 381-400.

Rawls, John. 1993. Political Liberalism. Chichester, NY: Columbia University Press.

- 1999a. The Law of Peoples. Cambridge, MA: Harvard University Press.

1999b. A Theory of Justice (Revised Edition). Cambridge, MA: Belknap Press of Harvard University Press.

Rodrik, Dani. 1999. The New Global Economy and Developing Countries: Making Openness Work. Washington: Overseas Development Council, and Baltimore: Johns Hopkins University Press.

Rudolph, Lloyd I, and Susanne Hoeber Rudolph. 1987. In Pursuit of Lakshmi: The Political Economy of the Indian State. Chicago: University of Chicago Press.

Rudolph, Susanne Hoeber and Lloyd I. Rudolph. 2000. "Living with Difference in India." Political Quarterly 71, 1 Supplement: 20-38.

Rudolph, Susanne Hoeber, Lloyd I. Rudolph, and Mohan Singh Kanota. 2002. Reversing the Gaze: Amar Singh's Diary, A Colonial Subject's Narrative of Imperial India. Boulder, CO: Westview Press. 
Sachs, Jeffrey D., Nirupam Bajpai, and Ananthi Ramiah. 2001. "Understanding Regional Economic Growth in India." Paper presented at Asian Economic Panel, Seoul, Korea, October 2001.

Sharma, Alakh N. 1995. "Political Economy of Poverty in Bihar." Economic and Political Weekly 30, 41 42: 2587-2602.

Singh, K. P. 2000. Antecedent Conditions for Collective Violence Against Dalits in India (Doctoral dissertation, University of Wisconsin-Madison, available from University of Wisconsin-Madison General Library System).

Sinha, Arvind K. 1988. Industrial Economy of a Backward Region. Delhi: Capital Publishing House. . 1996. "Social Mobilisation in Bihar: Bureaucratic Feudalism and Distributive Justice." Economic and Political Weekly 31, 51: 3287-3288.

Thakur, Sankarshan. 2000. The Making of Laloo Yadav: The Unmaking of Bihar. New Delhi: HarperCollins Publishers India.

_-_. 2002. "Sorry to Spoil Your Sunday," Sunday Express, 25 August 2002, at www.indianexpress.com/print.php?content_id $=824 \mathrm{C}$.

Wade, Robert. 1990. Governing the Market: Economic Theory and the Role of Government in East Asian Industrialization. Princeton: Princeton University Press.

Wood, Geof. 1999. "Private Provision after Public Neglect: Bending Irrigation Markets in North Bihar." Development and Change 30, 4: 775-794. 